\title{
Modulation of Cholinergic Neural Bronchoconstriction by Endogenous Nitric Oxide and Vasoactive Intestinal Peptide in Human Airways In Vitro
}

\author{
Jonathan K. Ward, Maria G. Belvisi, Alyson J. Fox, Motohiko Miura, Samad Tadjkarimi, * \\ Magdi H. Yacoub, * and Peter J. Barnes \\ Departments of Thoracic Medicine and ${ }^{*}$ Cardiothoracic Surgery, Royal Brompton \\ National Heart and Lung Institute, London SW3 6LY, United Kingdom
}

\begin{abstract}
Human airway smooth muscle possesses an inhibitory nonadrenergic noncholinergic neural bronchodilator response mediated by nitric oxide (NO). In guinea pig trachea both endogenous NO and vasoactive intestinal peptide (VIP) modulate cholinergic neural contractile responses. To identify whether endogenous NO or VIP can modulate cholinergic contractile responses in human airways in vitro, we studied the effects of specific NO synthase inhibitors and the peptidase $\alpha$-chymotrypsin on contractile responses evoked by electrical field stimulation (EFS) at three airway levels. Endogenous NO, but not VIP, was shown to inhibit cholinergic contractile responses at all airway levels but this inhibition was predominantly in trachea and main bronchus and less marked in segmental and subsegmental bronchi. To elucidate the mechanism of this modulation we then studied the effects of endogenous NO on acetylcholine ( $\mathrm{ACh}$ ) release evoked by EFS from tracheal smooth muscle strips. We confirmed that release was neural in origin, frequency dependent, and that endogenous NO did not affect ACh release. These findings show that endogenous NO, but not VIP, evoked by EFS can inhibit cholinergic neural responses via functional antagonism of $\mathrm{ACh}$ at the airway smooth muscle and that the contribution of this modulation is less marked in lower airways. ( J. Clin. Invest. 1993. 92:736-743.) Key words: acetylcholine release $\bullet$ functional antagonism $\bullet$ bronchodilation - parasympathetic innervation • inhibitory nonadrenergic noncholinergic (i-NANC)
\end{abstract}

\section{Introduction}

There is a prominent inhibitory nonadrenergic noncholinergic neural bronchodilator response (i-NANC) ${ }^{1}$ that is the only

Address reprint requests to Dr. M. G. Belvisi, Department of Thoracic Medicine, Royal Brompton National Heart \& Lung Institute, Dovehouse Street, London, SW3 6LY, UK.

Received for publication 7 August 1992 and in revised form 30 December 1992.

1. Abbreviations used in this paper: $\mathrm{ACh}$, acetylcholine; D-arg, D-arginine; D-NAME, D- $N^{\mathrm{G}}$-nitroarginine methyl ester; EFS, electrical field stimulation; i-NANC, inhibitory nonadrenergic noncholinergic; $\mathrm{KH}$, Krebs-Henseleit; L-arg, L-arginine; L-NAME, L- $N^{\mathrm{G}}$-nitroarginine methyl ester; L-NMMA, L- $N^{\mathrm{G}}$-monomethyl arginine; NO, nitric oxide; TTX, tetrodotoxin; VIP, vasoactive intestinal peptide.

J. Clin. Invest.

(c) The American Society for Clinical Investigation, Inc. 0021-9738/93/08/0736/07 \$2.00

Volume 92, August 1993, 736-742 neural relaxant response in human airways (1). The i-NANC response can be demonstrated in vitro by electrical field stimulation (EFS) (2-4) and in vivo by reflex stimulation of the larynx (5-7).

In guinea pig trachea in vitro the $\mathrm{i}-\mathrm{NANC}$ response is mediated by both vasoactive intestinal peptide (VIP) and nitric oxide (NO) $(8,9)$. This has been demonstrated by the partial inhibition of the i-NANC response by $\alpha$-chymotrypsin, which abolishes responses to exogenously applied VIP (10), and by $\mathrm{L}-N^{\mathrm{G}}$-monomethyl arginine ( $\mathrm{L}-\mathrm{NMMA}$ ) and L- $N^{\mathrm{G}}$-nitroarginine methyl ester (L-NAME) (9), which are both potent and selective inhibitors of NO synthesis (11). In human trachea in vitro VIP is a potent smooth muscle relaxant (2) but no evidence has been found for endogenous VIP mediating the iNANC response since concentrations of $\alpha$-chymotrypsin that abolish the response to exogenously applied VIP have no effect on the i-NANC response $(12,13)$. NO appears to be the major mediator involved in the $\mathrm{i}-\mathrm{NANC}$ response in human trachea in vitro with L-NAME producing complete inhibition of the low-frequency $(<5 \mathrm{~Hz})$, tetrodotoxin (TTX)-sensitive iNANC response $(12,13)$.

In human airways the major neurally mediated brochoconstrictor response is via the parasympathetic cholinergic innervation (1). Endogenous mediators of the i-NANC response may modulate cholinergic neural bronchoconstrictor responses. In vitro, endogenous VIP and NO have both been shown to inhibit cholinergic contractile responses evoked by EFS in the guinea pig trachea (14-16). It has been shown that inhibitors of NO synthesis do not increase acetylcholine ( $\mathrm{ACh}$ ) release in guinea pig tracheal strips, suggesting that NO is acting by functional antagonism of $\mathrm{ACh}$ at the airway smooth muscle and not by a prejunctional inhibition of $\mathrm{ACh}$ release from the nerve terminal.

In the present study we have used $\alpha$-chymotrypsin, LNMMA, and L-NAME to assess the modulatory effects of endogenous VIP and NO on functional cholinergic contractile responses to EFS at three airway levels ( trachea and main bronchus, segmental, and subsegmental bronchi), using normal human airways obtained from heart-lung transplantation donors. We have then investigated a possible mechanism for this modulation by measurement of $\mathrm{ACh}$ release.

\section{Methods}

\section{Lung samples}

Patients. We studied tissues from 23 nonsmoking, nonasthmatic donor patients (average age $28 \mathrm{yr}$ [range 5-49 yr], 13 male) for heart/ heart-lung transplantation. On the basis of previous medical histories and macroscopic histological inspection there was no evidence of longterm lung disease or airway inflammation in these donors. 
Tissues. Lung tissues were immediately placed into oxygenated Krebs-Henseleit $(\mathrm{KH})$ solution cooled to $4^{\circ} \mathrm{C}$ and transported to the laboratory. The composition of the $\mathrm{KH}$ was as follows $(\mathrm{mM}): 118$ $\mathrm{NaCl}, 5.9 \mathrm{KCl}, 1.2 \mathrm{MgSO}_{4}, 2.5 \mathrm{CaCl}_{2}, 1.2 \mathrm{NaH}_{2} \mathrm{PO}_{4}, 25.5 \mathrm{NaHCO}_{3}$, and 5.6 glucose. The airways were dissected from the parenchyma, making sure to remove the bronchial blood vessels. Experiments were carried out at three airway levels: trachea and main bronchus, in which smooth muscle was dissected free of cartilage/connective tissue and cut into strips; segmental airways, from bronchi with 3-10 mm i.d., which were cut into rings; and subsegmental airways, from bronchi with $<3 \mathrm{~mm}$ i.d., which were also cut into rings. Elapsed time between harvest of lungs from the donor and commencement of experiments was generally $6-8 \mathrm{~h}$.

\section{Measurement of contraction}

Tissue preparation. Tissues (strips or rings) were suspended by steel hooks in a 10-ml organ bath containing $\mathrm{KH}$ solution bubbled with $95 \%$ $\mathrm{O}_{2}, 5 \% \mathrm{CO}_{2}$ and maintained at $37^{\circ} \mathrm{C}(\mathrm{pH} 7.4)$. Indomethacin $\left(10^{-5}\right.$ $\mathrm{M}$ ) and propranolol $\left(10^{-6} \mathrm{M}\right.$ ) were present throughout to prevent inhibition of cholinergic responses caused by the possible release of endogenously produced prostaglandins or catecholamines, respectively. Tissues were connected via silk threads to force-displacement transducers (model FT-03; Grass Instrument Co., Quincy, MA) for measurement of isometric changes in tension, which were recorded on a polygraph (model 7D; Grass Instrument Co.). Tissues were allowed to equilibriate for $2 \mathrm{~h}$ with washing every $20 \mathrm{~min}$ and the tension was adjusted to $2.0 \mathrm{~g}$, which was found to be optimal for measuring changes in tension.

$E F S$. EFS was delivered by two platinum wire field electrodes inserted in parallel ( $10 \mathrm{~mm}$ apart $)$ with the tissue sample between them. A stimulator (model S88; Grass Instrument Co.) and a unity gain inverting amplifier provided biphasic square wave impulses with a supramaximal voltage of $40 \mathrm{~V}$ at source and $0.5 \mathrm{~ms}$ in duration. For experiments involving cholinergic contractile responses, stimulation frequencies of 1,4 , and $32 \mathrm{~Hz}$ were applied for $15 \mathrm{~s}$ every $4 \mathrm{~min}$.

Protocol. Atropine $\left(10^{-6} \mathrm{M}\right)$-sensitive, and hence cholinergic-contractile, responses were obtained to EFS at one stimulation frequency per tissue. The neural nature of the response was confirmed in some tissues by using the neuronal blocking drug TTX $\left(3 \times 10^{-6} \mathrm{M}\right)$. When at least three stable responses of equal magnitude were obtained to EFS, drugs were added. L-NAME $\left(10^{-7}\right.$ to $\left.10^{-4} \mathrm{M}\right)$, D-NAME $\left(10^{-4}\right.$ $\mathrm{M})$, L-NMMA $\left(10^{-4} \mathrm{M}\right)$, and L-arginine $\left(\mathrm{L}\right.$-arg; $\left.10^{-3} \mathrm{M}\right)$ have been shown to have maximal effects after 4-5 stimulations (16-20 min), and $\alpha$-chymotrypsin ( $2 \mathrm{U} / \mathrm{ml}$ ) after $15-20$ stimulations (60-80 $\mathrm{min}$ ) (15). When the effects of L-NAME or L-NMMA were maximal, L-arg $\left(10^{-3} \mathrm{M}\right)$ or D-arginine (D-arg; $\left.10^{-3} \mathrm{M}\right)$ were added. The effect of L-NAME $\left(10^{-4} \mathrm{M}\right)$ on cumulative concentration-response relationships to exogenously applied ACh $\left(10^{-9} \mathrm{M}-10^{-2} \mathrm{M}\right)$ was also studied. Results were expressed as a percentage of the maximal contractile response to $\mathrm{ACh}\left(10^{-2} \mathrm{M}\right)$ added at the end of each experiment to every tissue.

\section{Measurement of ACh release}

Measurement of $\mathrm{ACh}$ release has not previously been described for human airway smooth muscle. Apparatus for these experiments is much the same as Fox and Morton (17), who demonstrated release of $\mathrm{ACh}$ from the guinea pig ileum, however, experimental protocols, including dose cycle timing, tissue preparation, and stimulation parameters, have been modified to give optimal conditions for measurement of of $\left[{ }^{3} \mathrm{H}\right]$ release from human airway smooth muscle.

Tissue preparation. Strips of smooth muscle were taken from the trachea or main bronchi and all cartilage/connective tissue was dissected away. The epithelium was removed by careful dissection minimizing damage to the smooth muscle; this was confirmed later by macroscopic histology. Four tissues, in parallel, were connected top and bottom with silver wire (Goodfellows Metals, Cambridge, U.K.) and mounted in perfusion chambers. The perfusion rate was maintained at $1 \mathrm{ml} / \mathrm{min}$ throughout the experiment by a perfusion pump (model 503S; Smith and Nephew Watson-Marlow, Falmouth, UK). The per- fusion solution was made up of $\mathrm{KH}$ solution (composition previously described) bubbled with $95 \% \mathrm{O}_{2}, 5 \% \mathrm{CO}_{2}$ and maintained at $37^{\circ} \mathrm{C}(\mathrm{pH}$ 7.4). Indomethacin $\left(10^{-5} \mathrm{M}\right)$ and propranolol $\left(10^{-6} \mathrm{M}\right)$ were present throughout.

EFS. EFS was delivered by a stimulator (model S88; Grass Instrument Co.) via the silver wires. Square wave pulses with a supramaximal voltage of $40 \mathrm{~V}$ at source, 0.5 -ms duration, and frequencies between 1 and $64 \mathrm{~Hz}$ were used.

Loading with $\left[{ }^{3} \mathrm{H}\right]$ choline. Tissues were allowed to equilibriate during a 30-min period of continuous superfusion with $\mathrm{KH}$ solution, and EFS was applied for the last $10 \mathrm{~min}$ of this period $(40 \mathrm{~V}, 0.5 \mathrm{~ms}, 4$ $\mathrm{Hz}$ for $10 \mathrm{~min}$ ). Tissues were then placed into vials containing $1.5 \mathrm{ml}$ of oxygenated $\mathrm{KH}$ solution containing $\left[{ }^{3} \mathrm{H}\right]$ choline $(67 \mathrm{nmol} /$ liter $)$ and EFS was applied ( $40 \mathrm{~V}, 0.5 \mathrm{~ms}, 4 \mathrm{~Hz}$ for $45 \mathrm{~min}$ ) to allow uptake of $\left[{ }^{3} \mathrm{H}\right]$ choline into the tissues. At the end of this period superfusion is continued with $\mathrm{KH}$ solution containing hemicholininum-3 $\left(10^{-5} \mathrm{M}\right)$ to prevent reuptake of choline into the tissue. Preparations are then washed for $120 \mathrm{~min}$ with the superfusate being discarded; after $\sim 90$ min a stable baseline of $\left[{ }^{3} \mathrm{H}\right]$ release was achieved.

Protocol. EFS ( $40 \mathrm{~V}, 0.5 \mathrm{~ms}, 1-64 \mathrm{~Hz}$ for $3 \mathrm{~min}$ ) was applied at $\sim 25$-min intervals. Samples $(1 \mathrm{ml})$ were taken at 1 -min intervals for 3 min before, during, and after EFS and at 5-min intervals outside these times. Frequency-release relationships were compiled. TTX $\left(3 \times 10^{-6}\right.$ M) was added after a control stimulation ( $40 \mathrm{~V}, 0.5 \mathrm{~ms}, 32$ or $64 \mathrm{~Hz}$ for $3 \mathrm{~min}$ ) and $\geq 10 \mathrm{~min}$ before a test stimulation with the same parameters, to study if release was neurally mediated. ACh $\left(10^{-5} \mathrm{M}\right)$ was added, as this dose gave a contraction similar to 4-Hz EFS $(1,238 \pm 315$ $\mathrm{mg}, n=4$ for $\mathrm{ACh} 10^{-5} \mathrm{M} ; 1,540 \pm 303 \mathrm{mg}, n=18$ for $4-\mathrm{Hz} \mathrm{EFS}$ ), to study if contraction of the tissue increases $\left[{ }^{3} \mathrm{H}\right]$ release. A frequency of $4 \mathrm{~Hz}$ was chosen for subsequent experiments as it gave a significant but submaximal increase in $\left[{ }^{3} \mathrm{H}\right]$ release. L-NAME $\left(10^{-4} \mathrm{M}\right)$ was added to the superfusate after two control 4-Hz EFS and $\geq 10$ min before two test 4-Hz EFS; L-arg $\left(10^{-3} \mathrm{M}\right)$ was added after this and $10 \mathrm{~min}$ before a final test 4-Hz EFS. At the end of the experiment tissues were solubilized in $1 \mathrm{ml}$ of Soluene tissue solubilizer (Canberra Packard, Pangboune, UK). All samples of superfusate and solubilized tissues were aliquoted to $1 \mathrm{ml}$ and assayed for radioactivity by a liquid scintillation counter (model 1900EA; Packard Instrument Co. Inc., Meriden, CT). Fractional release of initial $\left[{ }^{3} \mathrm{H}\right]$ content was calculated as a rate coefficient $\left(\mathrm{min}^{-1}\right)$ as previously described $(17)$. The increase in $\left[{ }^{3} \mathrm{H}\right]$ overflow evoked by EFS was expressed as a percentage increase in the average rate coefficient during the 3-min EFS period over the average for the preceding 3-min control period.

\section{Drugs}

The following drugs were used: indomethacin, TTX, L-NMMA, L-arg, D-arg, ACh, $\alpha$-chymotrypsin, and hemicholinium-3 (Sigma Chemical Co., Dorset, UK); L- and D-NAME (Bachem Feinchemikalien AG., Bupendorf, Switzerland); atropine sulfate (Pharma Hameln GmbH, Hamburg, Germany); propranolol hydrochloride (Imperial Chemical Industries, Cheshire, UK); [ methyl- $\left.{ }^{3} \mathrm{H}\right]$ choline chloride (Amersham Int., Amersham, UK). KH solution was made up fresh each day. Aliquots of drugs were dissolved in distilled water and stored at $-20^{\circ} \mathrm{C}$ for $\leq 1$ wk. Indomethacin was made up in an alkaline phosphate buffer $(\mathrm{pH} 7.8)$ of the following composition $(\mathrm{mM}): 20 \mathrm{KH}_{2} \mathrm{PO}_{4}, 120$ $\mathrm{Na}_{2} \mathrm{HPO}_{4}$. Drug additions did not exceed $1 \%$ of the bath volume. All concentrations refer to the final bath concentrations.

\section{Statistical analysis}

Data are expressed as mean \pm SE. Contractile responses were expressed as a percentage of a maximum contraction to $\mathrm{ACh}\left(10^{-2} \mathrm{M}\right)$. In the experiments using EFS where each tissue was its own control, results before and after drug treatment were compared by a Student's $t$ test for paired data. Experiments involving cumulative concentration-dependent contractions to exogenously applied concentrations of $\mathrm{ACh}$ required to cause $50 \%$ of the maximal response $\left(\mathrm{EC}_{50}\right)$ values are calculated by iterative curve fitting using Graphpad Inplot (Graphpad Inc.). 
and results were compared between control and test groups using the Student's $t$ test for unpaired data. $P$ values $<0.05$ were considered significant.

\section{Results}

The neuromodulatory effects of endogenous NO and VIP on cholinergic neurotransmission in human airways

The effect of NO synthase inhibitors on cholinergic contractile responses to EFS in trachea and main bronchus. L-NAME $\left(10^{-4} \mathrm{M}\right)$ potentiated cholinergic contractile responses to EFS $(4 \mathrm{~Hz})$ by $65.1 \pm 14.2 \%(n=8, P<0.001)$ (Figs. 1 and 2$)$. L-NMMA $\left(10^{-4} \mathrm{M}\right)$ also produced a potentiation of this cholinergic contractile response but was less potent than L-NAME $\left(10^{-4} \mathrm{M}\right)$, with an enhancement of $27.5 \pm 5.1 \%(n=4, P$ $<0.05$ ) (Fig. 2). L-NAME was chosen for subsequent experiments as it was the more potent NO synthase inhibitor. L$\operatorname{NAME}\left(10^{-7}\right.$ to $\left.10^{-4} \mathrm{M}\right)$ produced a concentration-dependent enhancement of the cholinergic contractile response to EFS (4 $\mathrm{Hz})$, giving $3.7 \pm 2.1 \%(n=5, \mathrm{NS}), 10.9 \pm 2.2 \%(n=4, \mathrm{NS})$, $25.3 \pm 4.0 \%(n=5, P<0.01)$, and $65.1 \pm 14.2 \%(n=8, P$ $<0.001$ ) enhancement, respectively.

A

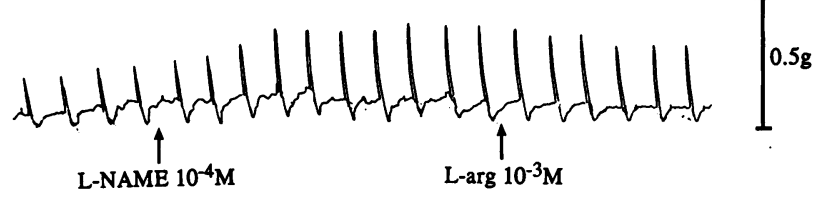

B

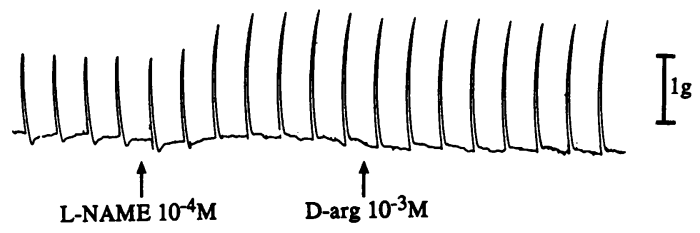

C

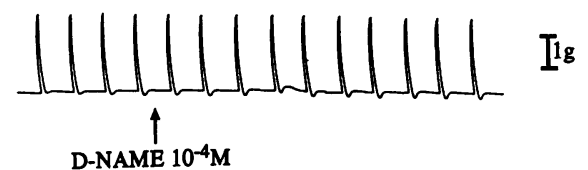

D

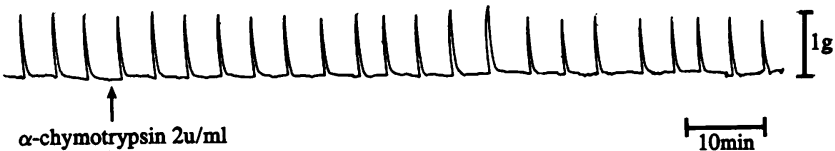

Figure 1. Trace showing the effects of D-/L- $N^{\mathrm{G}}$-nitroarginine methyl ester ( $D-N A M E ; L-N A M E)$ and $\alpha$-chymotrypsin on cholinergic contractile responses elicited to EFS ( $40 \mathrm{~V}, 0.5 \mathrm{~ms}, 4 \mathrm{~Hz}$ for $15 \mathrm{~s}$ every $4 \mathrm{~min}$ ) in human main airways. ( $A$ and $B$ ) The enhancement of the contractile response by L-NAME $\left(10^{-4} \mathrm{M}\right)$ and its reversal by $(A)$ L-arginine $\left(L-\arg 10^{-3} M\right)$, but not by $(B) D$-arginine $\left(D-\arg 10^{-3} M\right)$. (C) D-NAME $\left(10^{-4} \mathrm{M}\right)$, the inactive isomer of L-NAME, has no effect on the contractile response. $(D) \alpha$-Chymotrypsin $(2 \mathrm{U} / \mathrm{ml})$, the peptidase that degrades VIP and related peptides, also has no effect on contractile responses.

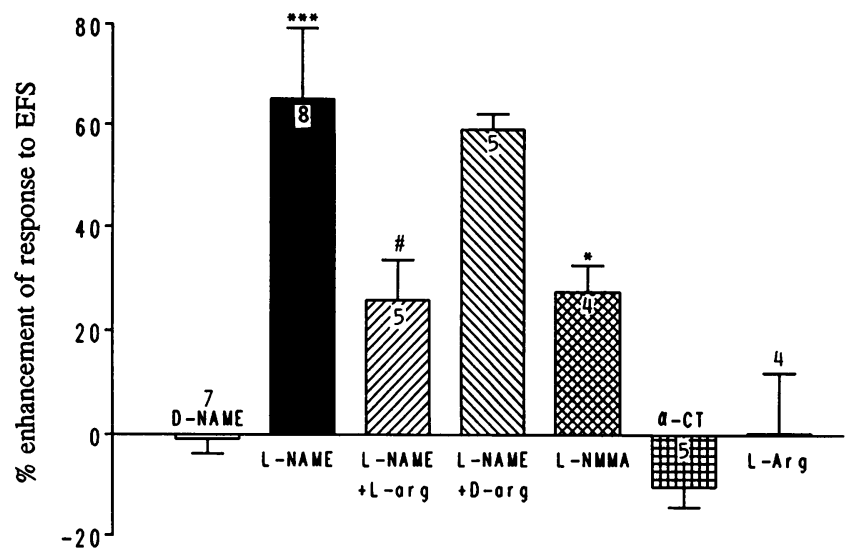

Figure 2. Histogram showing the effects NO synthase inhibitors and $\alpha$-chymotrypsin on cholinergic contractile responses evoked by EFS $(40 \mathrm{~V}, 0.5 \mathrm{~ms}, 4 \mathrm{~Hz}$ for $15 \mathrm{~s}$ every $4 \mathrm{~min}$ ) in human main airways. Effects are displayed as a mean percentage enhancement of the mean initial response preceding drug administration. L-NAME $\left(10^{-4} \mathrm{M}\right)$ causes a significant enhancement of the contractile response which is partially reversed by $\mathrm{L}-\arg \left(10^{-3} \mathrm{M}\right)$ but not by D-arg $\left(10^{-3} \mathrm{M}\right)$. LNMMA $\left(10^{-4} \mathrm{M}\right)$ also significantly enhances contractile responses but less markedly than L-NAME $\left(10^{-4} \mathrm{M}\right) . \alpha$-Chymotrypsin $(\alpha-C T$; $2 \mathrm{U} / \mathrm{ml})$, D-NAME $\left(10^{-4} \mathrm{M}\right)$, and L-arg $\left(10^{-3} \mathrm{M}\right)$ have no significant effect on contractile responses. Vertical bars represent mean $\pm \mathrm{SE}$. ${ }^{*} P<0.05,{ }^{* * *} P<0.001$ compared with control values preceding drug administration. ${ }^{*} P<0.05$ compared with values after administration of L-NAME $\left(10^{-4} \mathrm{M}\right)$. Numbers inside bars refer to the number of patients studied.

The effect of EFS frequency on L-NAME enhancement of cholinergic contractile responses in trachea and main bronchus. Three different EFS frequencies were chosen $(1,4$, and $32 \mathrm{~Hz})$ to represent the full range of the cholinergic frequency-response relationship. Once constant cholinergic contractile responses to EFS were obtained, L-NAME $\left(10^{-4} \mathrm{M}\right)$ was added. Enhancement of the cholinergic response evoked by L-NAME was found to be maximal at $4 \mathrm{~Hz}(65.1 \pm 14.2 \%, n=8, P$ $<0.001)$ and reduced at $1(22.5 \pm 6.9 \%, n=4, P<0.05)$ and 32 $\mathrm{Hz}(13.8 \pm 5.4 \%, n=4, P<0.05)$. Subsequently $4 \mathrm{~Hz}$ was chosen as the optimal frequency to study modulation of the cholinergic response.

Specificity of the enhancement of the cholinergic contractile response to EFS by L-NAME in trachea and main bronchus. When constant cholinergic contractile responses to $\operatorname{EFS}(4 \mathrm{~Hz})$ were obtained, L-NAME $\left(10^{-4} \mathrm{M}\right)$, its inactive enantiomer D-NAME $\left(10^{-4} \mathrm{M}\right)$, (Fig. 1), or the NO synthase substrate $\mathrm{L}-\arg \left(10^{-3} \mathrm{M}\right)$ were added. When the enhancement produced by L-NAME was maximal $(12-16 \mathrm{~min}) \mathrm{L}$-arg $\left(10^{-3} \mathrm{M}\right)$ or its inactive enantiomer D-arg $\left(10^{-3} \mathrm{M}\right)$ were added (Fig. 1). DNAME was found to have no significant effect on the cholinergic contractile response (Fig. 2). L-NAME produced a significant enhancement $(65.1 \pm 14.2 \%, n=8, P<0.001)$, which was partially reversed by L-arg $(60.2 \pm 11.9 \%$ reversal, $n=5, P$ $<0.05$ ) but not by D-arg $(9.2 \pm 4.6 \%, n=5)$ (Figs. 1 and 2 ). $\mathrm{L}$-arg $\left(10^{-3} \mathrm{M}\right)$ alone had no effect on the cholinergic contractile response $(0.3 \pm 11.7 \%, n=4)$ (Fig. 2$)$.

Effect of the peptidase $\alpha$-chymotrypsin on cholinergic contractile responses to EFS in trachea and main bronchus. When constant cholinergic contractile responses to $\mathrm{EFS}(4 \mathrm{~Hz})$ were obtained, $\alpha$-chymotrypsin $(2 \mathrm{U} / \mathrm{ml})$ was added and incubated 
for a period of $80-90 \mathrm{~min}$. Throughout this time the tissue underwent $\mathrm{EFS}(4 \mathrm{~Hz}, 0.5 \mathrm{~ms}, 40 \mathrm{~V}$ for $15 \mathrm{~s}$ every $4 \mathrm{~min}$ ) to facilitate degradation of any evoked VIP (Fig. 1). $\alpha$-Chymotrypsin had no significant effect on cholinergic responses (Fig. 2).

Effect of $L-N A M E$ on concentration-response relationships to exogenously applied ACh in trachea and main bronchus. $\mathrm{ACh}\left(10^{-9}\right.$ to $\left.10^{-2} \mathrm{M}\right)$ was given to two groups of tissues, one of which had been preincubated with L-NAME $\left(10^{-4} \mathrm{M}\right)$ for 20 min, the other being incubated with an equal volume of distilled water $(10 \mu \mathrm{l})$ for the same time period. It was found that L-NAME did not significantly effect either the maximum response to ACh (control: $3,969 \pm 754 \mathrm{mg}, n=3$; +L-NAME: $3,524 \pm 741 \mathrm{mg}, n=4$ ) or the $\mathrm{EC}_{50}$ (control: $4.1 \pm 0.9 \times 10^{-5} \mathrm{M}$, $n=3$; +L-NAME: $\left.4.5 \pm 0.8 \times 10^{-5} \mathrm{M}, n=4\right)$.

Effect of $L-N A M E, L-N M M A$, and $\alpha$-chymotrypsin on cholinergic contractile responses at three different airway levels. Tissues were taken from either trachea and main bronchus, segmental, or subsegmental airways. When constant cholinergic contractile responses to EFS ( $4 \mathrm{~Hz}$ ) were obtained, either L-NAME $\left(10^{-4} \mathrm{M}\right)$, L-NMMA $\left(10^{-4} \mathrm{M}\right)$, or $\alpha$-chymotrypsin ( $2 \mathrm{U} / \mathrm{ml}$ ) were added. L-NAME produced a significant enhancement was maximal in trachea and main bronchus (65.1 $\pm 14.2 \%, n=8, P<0.001)$ and smaller in segmental

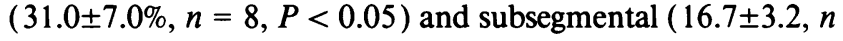
$=4, P<0.05$ ) airways (Fig. 3). L-NMMA also produces an enhancement but this is again more prominent in trachea and main bronchus $(27.5 \pm 5.1 \%, n=4, P<0.05)$, becoming smaller in segmental $(7.3 \pm 3.0 \%, n=4, P<0.05)$ and subsegmental airways (6.7 $\pm 3.5 \%, n=2$, NS) (Fig. 3). $\alpha$-Chymotrypsin had no significant effect at any airway level (Fig. 3 ). The degree of cholinergic contraction to $\operatorname{EFS}(4 \mathrm{~Hz})$ was not signifi-

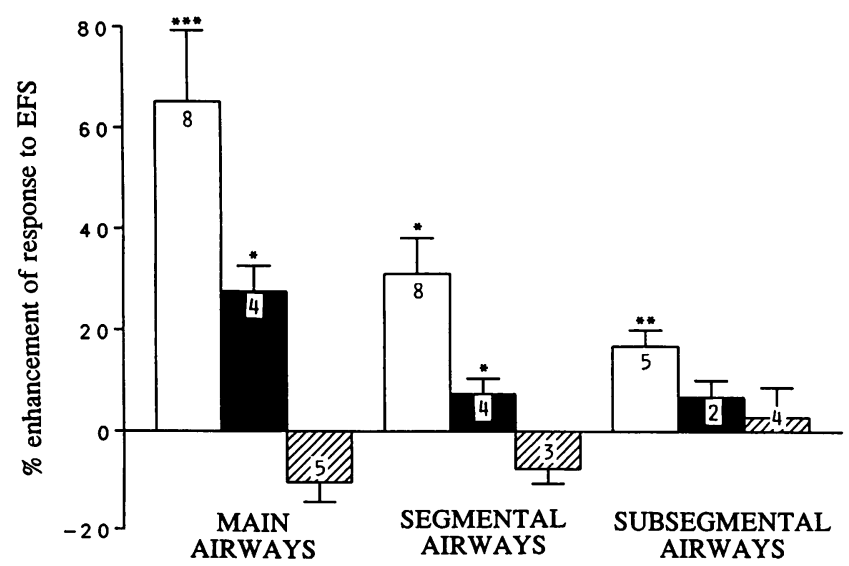

Figure 3. Histogram showing the effect of NO synthase inhibitors or $\alpha$-chymotrypsin on the cholinergic contractile response to EFS (40 $\mathrm{V}, 0.5 \mathrm{~ms}, 4 \mathrm{~Hz}$ for $15 \mathrm{~s}$ every $4 \mathrm{~min}$ ) in main, segmental, and subsegmental airways. Effects are displayed as a mean percentage enhancement of the mean initial response preceeding drug administration. L-NAME ( $10^{-4} \mathrm{M}$; open columns) produces significant enhancement at all airway levels but this is maximal in main airways and less in segmental and subsegmental airways. L-NMMA $\left(10^{-4} \mathrm{M}\right.$; filled columns) produced much the same pattern of enhancement but has not yet been shown to be significant in subsegmental airways. $\alpha$-Chymotrypsin ( $2 \mathrm{U} / \mathrm{ml}$; hatched columns) had no significant effect at any airway level. Vertical bars indicate mean \pm SE. ${ }^{*} P<0.05,{ }^{* *} P$ $<0.01,{ }^{* * *} P<0.001$ compared with values preceding drug administration. Numbers inside bars refer to the number of patients studied. cantly different at any airway level. If raw tension data are analyzed there is a reduction in tension induced by EFS in segmental and subsegmental airways (trachea and main bronchus: $1,540 \pm 303 \mathrm{mg}, n=18$; segmental: $962 \pm 259 \mathrm{mg}, n=10$; subsegmental: $685 \pm 126 \mathrm{mg}, n=7$ ), but this does not reach significance. Similarly if data are compared as a percentage of the maximum contractile response to exogenous acetylcholine $\left(\mathrm{ACh}_{\max }\right)$, there is no difference between airways as the $\mathrm{ACh}_{\max }$ also decreases down the airways (trachea and main bronchus: $44.4 \pm 5.2 \%, \mathrm{ACh}_{\max }=2,761 \pm 426 \mathrm{mg}, n=18$; segmental airways: $35.5 \pm 5.4 \%, \mathrm{ACh}_{\max }=2,581 \pm 426 \mathrm{mg}, n=10$; subsegmental: $\left.43.7 \pm 5.9 \%, \mathrm{ACh}_{\max }=1,562 \pm 159 \mathrm{mg}, n=7\right)$.

\section{The mechanism of cholinergic modulation by L-NAME}

Neuronal nature of $A C h$ release from trachea and main bronchus evoked by EFS. Once a stable baseline of $\left[{ }^{3} \mathrm{H}\right]$ release is reached, two groups of tracheal or main bronchial smooth muscle were taken and EFS was applied at 32 or $64 \mathrm{~Hz}$ for 3 min either in the absence or presence of the selective neuronal blocking drug TTX $\left(3 \times 10^{-6} \mathrm{M}\right)$. TTX significantly reduced the enhancement of $\left[{ }^{3} \mathrm{H}\right]$ release evoked by EFS at both 32 and $64 \mathrm{~Hz}$ (Fig. 4). In another group of tissues, also taken from trachea or main bronchus, once a stable baseline of $\left[{ }^{3} \mathrm{H}\right]$ release was reached $\mathrm{ACh}\left(10^{-5} \mathrm{M}\right)$ was added to assess whether contraction itself caused nonspecific $\left[{ }^{3} \mathrm{H}\right]$ release. ACh did not evoke a significant increase in $\left[{ }^{3} \mathrm{H}\right]$ release (Fig. 4). From these results it was assumed that $\left[{ }^{3} \mathrm{H}\right]$ overflow evoked by EFS was neural in origin.

Frequency-response relationship of $A C h$ release evoked by EFS from trachea or main bronchus. Once a stable baseline of [ ${ }^{3} \mathrm{H}$ ] release had been achieved, EFS was applied for $3 \mathrm{~min}$ approximately every $25 \mathrm{~min}$ at frequencies between 1 and 64

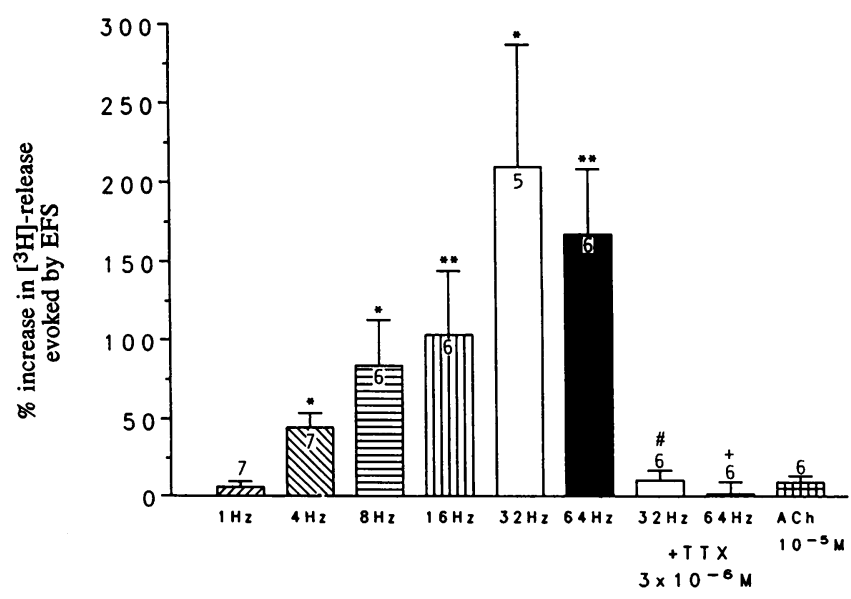

Figure 4. Histogram showing the frequency-response relationship and neuronal origin of $\mathrm{ACh}$ release, evoked by EFS ( $40 \mathrm{~V}, 0.5 \mathrm{~ms}, 1-64$ $\mathrm{Hz}$ for $3 \mathrm{~min}$ every $20 \mathrm{~min}$ ), from human main airways. Effects are displayed as a percentage enhancement of the mean baseline of $\left[{ }^{3} \mathrm{H}\right]$ release preceding EFS. EFS produced a frequency-dependent increase in $\left[{ }^{3} \mathrm{H}\right]$ release, which is significant between 4 and $64 \mathrm{~Hz}$ and is maximal by $32 \mathrm{~Hz}$. TTX $\left(3 \times 10^{-6} \mathrm{M}\right)$ significantly reduced the 32 - and 64-Hz responses. ACh $\left(10^{-5} \mathrm{M}\right)$ did not significantly increase baseline $\left[{ }^{3} \mathrm{H}\right]$ release. Vertical bars represent mean \pm SE. ${ }^{*} P<0.05,{ }^{* *} P$ $<0.01$ compared with baseline release preceding EFS. ${ }^{*} P<0.05$ compared with $32 \mathrm{~Hz}$ EFS before TTX administration. ${ }^{\dagger} P<0.05$ compared with $64 \mathrm{~Hz}$ EFS before TTX administration. Numbers inside bars refer to the number of patients studied. 
Hz. $\left[{ }^{3} \mathrm{H}\right]$ release increased in a frequency-dependent manner, with a significant increase between 4 and $64 \mathrm{~Hz}(4 \mathrm{~Hz}$ :

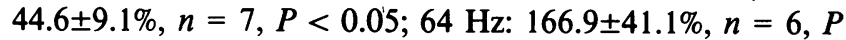
$<0.05)$ and was maximal by $32 \mathrm{~Hz}(209.5 \pm 77.4 \%, n=5, P$ $<0.05$ )(Fig. 4). Subsequently $4 \mathrm{~Hz}$ EFS was chosen for use in further experiments as it produced a significant but submaximal increase in $\left[{ }^{3} \mathrm{H}\right]$ release and was equivalent to that used in experiments investigating the effects of L-NAME on functional cholinergic neural responses to EFS.

The effect of L-NAME on ACh release evoked by EFS from trachea or main bronchus. Once a stable baseline of $\left[{ }^{3} \mathrm{H}\right]$ release has been achieved then $\mathrm{EFS}(40 \mathrm{~V}, 0.5 \mathrm{~ms}, 4 \mathrm{~Hz}$ for $3 \mathrm{~min}$ every $20 \mathrm{~min}$ approximately) was applied. After two control stimulations L-NAME $\left(10^{-4} \mathrm{M}\right)$ was added and then after two test stimulations L-NAME $\left(10^{-4} \mathrm{M}\right)$ and L-arg $\left(10^{-3} \mathrm{M}\right)$ were added (Fig. $5 \mathrm{~A}$ ). EFS $(4 \mathrm{~Hz})$ produced an increase in $\left[{ }^{3} \mathrm{H}\right]$ release of $60.9 \pm 13.6 \%(n=4, P<0.05)$. There was no significant enhancement of this release by L-NAME $\left(10^{-4} \mathrm{M}\right)$ $(61.8 \pm 10.9 \%$ increase in release, $n=4)$ or by L-NAME $\left(10^{-4}\right.$ $\mathrm{M})$ and L-arg $\left(10^{-3} \mathrm{M}\right)(55.7 \pm 13.5 \%$ increase in release, $n=4)$ (Fig. $5 \mathrm{~B}$ ).

\section{Discussion}

In this study we have shown that endogenous NO but not VIP can modulate cholinergic neural contractile responses in human airway smooth muscle in vitro. L-NAME $\left(10^{-7}-10^{-4} \mathrm{M}\right)$, a potent and specific inhibitor of NO synthase (11), had no effect on resting tone but produced a concentration-dependent enhancement of the cholinergic neural constrictor response to EFS without affecting cumulative concentration-response relationships to exogenously applied $\mathrm{ACh}$. This suggests there is no basal release of NO and that EFS evokes endogenous NO, which acts to inhibit cholinergic contractile responses. Looking at the frequency-dependent nature of this enhancement by $\mathrm{L}$ NAME $\left(10^{-4} \mathrm{M}\right)$, we found that it was significant at all frequencies $(1,4$, and $32 \mathrm{~Hz}$ ) but was maximal at $4 \mathrm{~Hz}$ and smaller at 1 and $32 \mathrm{~Hz}$. This is not surprising since the i-NANC responses in human trachea and main bronchus are maximal between 5 and $10 \mathrm{~Hz}(12,13)$ whereas cholinergic responses are maximal between 32 and $64 \mathrm{~Hz}$ (18). Thus at $1 \mathrm{~Hz}$ both the i-NANC response and $\mathrm{ACh}$ release are small so that moderate enhancement of cholinergic bronchoconstriction is observed, at $4 \mathrm{~Hz}$ the i-NANC response is almost maximal but $\mathrm{ACh}$ release is relatively low and so a larger enhancement is observed, but at $32 \mathrm{~Hz}$ the i-NANC response is less but ACh release is maximal, so that only moderate enhancement is observed. We showed the specificity of the effect of L-NAME on cholinergic responses to EFS as its inactive enantiomer D-NAME (11) had no effect, and the effect of L-NAME $\left(10^{-4} \mathrm{M}\right)$ was partially reversed by $\mathrm{L}-\arg \left(10^{-3} \mathrm{M}\right)$ but not by $\mathrm{D}$-arg, which is not a substrate for NO synthase.

There are several possible reasons why reversal by $L$-arg is not complete. L-NAME may be very strongly bound to the NO synthase enzyme and hence a higher concentration of L-arg $\left(>10^{-2} \mathrm{M}\right)$ is required for complete reversal by competition for the active site of the enzyme, or L-NAME and L-arg may have different abilities to access intact cells. These enantiomerspecific effects are also observed in other NO-mediated systems, for example, endothelium-derived relaxing factor mediated relaxations of vascular smooth muscle (19) and i-

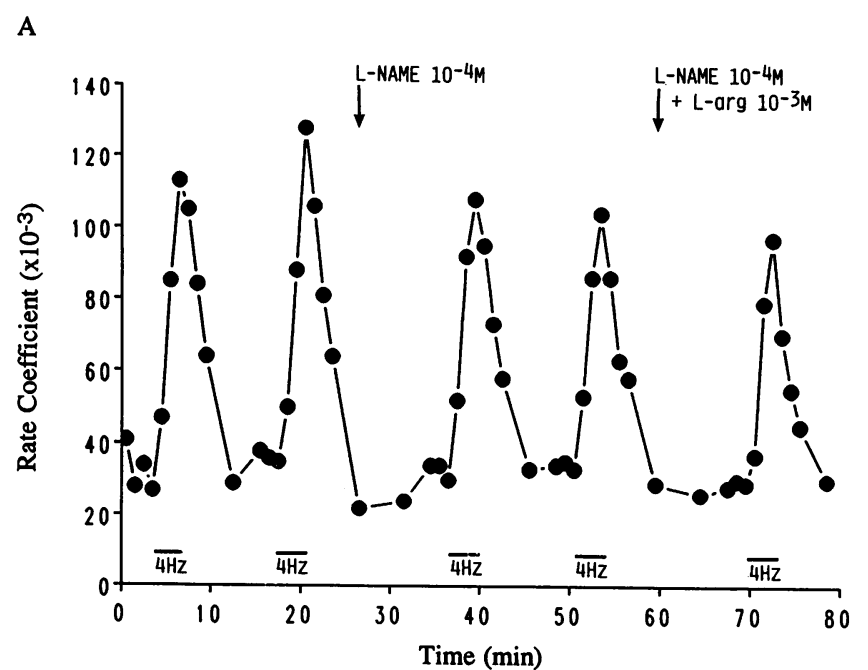

B

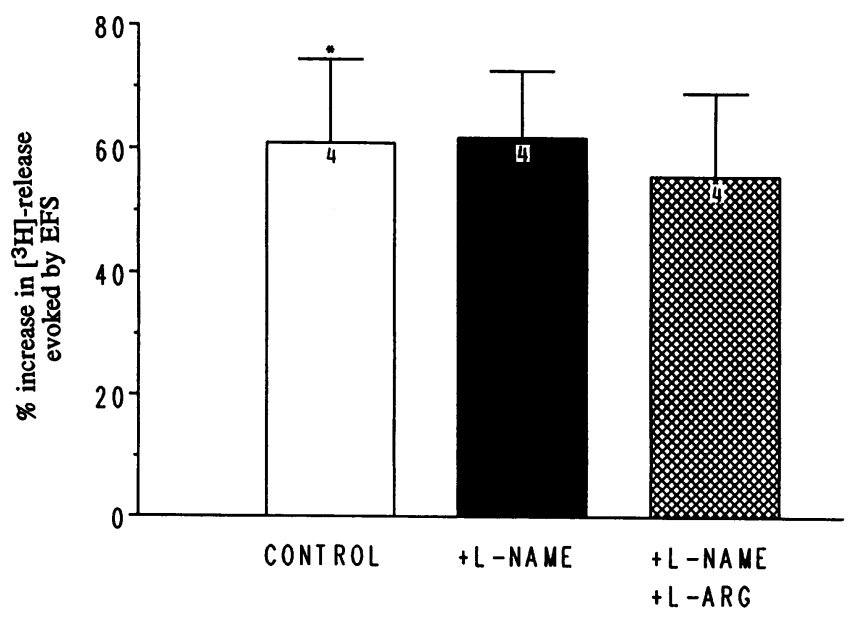

Figure 5. The effect of L-NAME on ACh release evoked by EFS (40 $\mathrm{V}, 0.5 \mathrm{~ms}, 4 \mathrm{~Hz}$ for $3 \mathrm{~min}$ every $20 \mathrm{~min}$ approximately) from human main airways. $(A)$ Profile of ACh release from single tracheal strip. Results are expressed as a rate coefficient $\left(\times 10^{-3} \mathrm{M}\right)$, which is a measure of the fractional $\left[{ }^{3} \mathrm{H}\right]$ release plotted against time ( $\mathrm{min}$ ). EFS $(4 \mathrm{~Hz})$ produces a reproducible increase in $\left[{ }^{3} \mathrm{H}\right]$ release, which is unaffected by L-NAME $\left(10^{-4} \mathrm{M}\right)$ or L-NAME $\left(10^{-4} \mathrm{M}\right)$ and L-arg $\left(10^{-3} \mathrm{M}\right)$. ( $\left.B\right)$ Histogram showing mean data for four patients. Results are expressed as a percentage enhancement of the mean baseline of $\left[{ }^{3} \mathrm{H}\right]$ release preceding EFS. There is no significant difference between control (open column), +L-NAME $\left(10^{-4} \mathrm{M}\right)$ (filled column), or +L-NAME $\left(10^{-4} \mathrm{M}\right) / \mathrm{L}-\arg \left(10^{-3} \mathrm{M}\right)$ (hatched column). Vertical bars refer to mean \pm SE. ${ }^{*} P<0.05$ compared with baseline release preceding EFS.

NANC responses in many other tissues $(20,21)$, including anococcygeus muscle of the rat and mouse $(22,23)$, rat gastric fundus (24), as well as guinea pig trachea $(8,9)$. L-arg had no effect on resting tone or cholinergic contractile responses, suggesting that the supply of $\mathrm{L}$-arg is not a rate-limiting step in the synthesis of NO in this tissue.

L-NMMA was also found to enhance cholinergic contractile responses but less effectively than L-NAME at the same concentration $\left(10^{-4} \mathrm{M}\right)$; this corresponds well with NO-mediated responses both from endothelial cells (11) and neurally 
mediated i-NANC responses $(9,14)$. Explanation of this potency difference is unclear, it may be that L-NMMA is less effective as it can also act as a substrate for NO synthase (25) or that it is due to an effect other than the inhibition of the enzyme per se. For example, L-NMMA, but not L-NAME, has recently been shown to inhibit the endothelial cell $\mathrm{L}$-arg transporter (26) and thus may inhibit its own uptake into cells.

$\alpha$-Chymotrypsin, at a concentration shown to inhibit VIPinduced neural responses in guinea pig trachea (10) and abolish responses to exogenously applied VIP in human trachea $(12,13)$, had no effect on cholinergic contractile responses to EFS. This suggests that endogenous VIP does not modulate cholinergic transmission in human trachea, exposing a marked difference from the guinea pig airways where both endogenous NO and VIP have been shown to inhibit cholinergic contractile responses (14). This is also a somewhat surprising result as it has been shown that there are large amounts of VIP-immunoreactive nerves in human tracheal smooth muscle (27), but it may be that VIP is more important in vasodilation, as it has been shown to be a potent vasodilator in human pulmonary vasculature (28).

We found that L-NAME showed greatest enhancement of cholinergic contractile responses in main airways and this becomes smaller in segmental and, again, in subsegmental airways. L-NMMA showed the same pattern of enhancement but again was less effective than the same concentration of $\mathrm{L}$ NAME at all airway levels. $\alpha$-Chymotrypsin had no significant effect at any airway level. Cholinergic contractile responses were not significantly different at any airway level. Hence modulation of the cholinergic contractile response by endogenous NO is most prominent in large airways, possibly suggesting that the NO-mediated i-NANC response is less prominent in lower airways. This is in agreement with the observation that in cat (29) and bovine (30) airways neurally mediated i-NANC responses are less prominent in the distal regions of the tracheobronchial tree and more prominent in the larger conducting regions.

Measurement of ACh release has not previously been characterized in human tracheal smooth muscle. It would be preferable to measure ACh release directly (31), however, this technique has several disadvantages. Minimum detection levels are often high, leading to low assay sensitivity, and ACh esterase inhibitors, together with uptake inhibitors, would have to be used, increasing the chance of activation of prejunctional autoreceptors. We have used the technique of measuring $\left[{ }^{3} \mathrm{H}\right]$ overflow, evoked by EFS, from tissues preincubated with $\left[{ }^{3} \mathrm{H}\right]$ choline. This technique also has its disadvantages: it is difficult to determine if evoked overflow is neural in origin, if overflow is a true reflection of actual release, whether the labeled choline is solely incorporated into $\left[{ }^{3} \mathrm{H}\right] \mathrm{ACh}$, and if so whether $\left[{ }^{3} \mathrm{H}\right] \mathrm{ACh}$ acts in the same way as unlabeled ACh. Hence in a preliminary study we looked at the frequency-dependent nature and neuronal origin of $\left[{ }^{3} \mathrm{H}\right]$ release evoked by EFS. We have shown that there is a frequency-dependent increase in $\left[{ }^{3} \mathrm{H}\right]$ release between 1 and $64 \mathrm{~Hz}$ and that this is maximal at $32 \mathrm{~Hz}$. This closely mimics the frequency-response curve for cholinergic contractile responses evoked by EFS in human tracheal smooth muscle in vitro (18). TTX, a selective neuronal blocking agent, significantly attenuated release evoked by EFS at 32 and $64 \mathrm{~Hz}$. ACh, added exogenously, did not significantly increase $\left[{ }^{3} \mathrm{H}\right]$ release, showing that contrac- tion of the tissue itself did not cause a nonneuronal release. We therefore conclude that release is neuronal in origin, although we cannot conclude that the increase in $\left[{ }^{3} \mathrm{H}\right]$ release is solely via an increase in $\mathrm{ACh}$ release without further experiments. However, it has been shown that in guinea pig tracheal strips $\left[{ }^{3} \mathrm{H}\right]$ release evoked by EFS, in the presence of indomethacin and with the epithelium removed, is almost solely composed of $\left[{ }^{3} \mathrm{H}\right] \mathrm{ACh}$ with only low levels of $\left[{ }^{3} \mathrm{H}\right]$ choline and $\left[{ }^{3} \mathrm{H}\right]$ phosphorylcholine (32). Hence it would seem reasonable to assume that in our experiments $\left[{ }^{3} \mathrm{H}\right]$ release is a good marker for measurement of neuronally evoked $\mathrm{ACh}$ release. We found that we could achieve at least five reproducible peaks of $\left[{ }^{3} \mathrm{H}\right]$ release to EFS $(4 \mathrm{~Hz})$ and that L-NAME had no effect on these peaks. It therefore appears that endogenous NO does not modulate cholinergic contractile responses by prejunctional inhibition of $\mathrm{ACh}$ release from the nerve terminal, and this corresponds well with previous observations in guinea pig trachea (16).

In conclusion, we have shown that endogenous NO, but not VIP, released by EFS can produce a marked inhibition of cholinergic contractile responses in vitro and that this modulation becomes less pronounced in lower airways. It also appears that this effect is produced by NO acting postjunctionally by functional antagonism of $\mathrm{ACh}$ at the level of the airway smooth muscle. The simplest visualization of functional antagonism would be that NO is acting to cause bronchodilation, possibly by stimulating guanylate cyclase leading to guanosine $3^{\prime}, 5^{\prime}$ cyclic monophosphate (cGMP) formation, which could directly oppose cholinergic bronchoconstriction. Without further experiments measuring cyclic nucleotide levels, for example, this is a purely speculative mechanism. Whether NO is released as a neurotransmitter or is a mediator controlled by an unidentified classical neurotransmitter is unclear. If NO is released as a neurotransmitter then it is not clear which population of nerves it is released from. It is not yet known whether NO is colocalized with $\mathrm{ACh}$ in cholinergic nerves in the airways and, hence, there may be a discreet population of i-NANC nerves as yet undiscovered. These findings may also be important in acute airway inflammatory diseases such as asthma. NO may be more rapidly degraded at inflammatory sites by superoxide anions, which are produced by activated inflammatory cells (33). If there is a more rapid degradation of NO in asthma then, as our results have shown, enhanced cholinergic bronchoconstriction could occur and evidence has shown that bronchoconstriction of this kind is the principle reversible element in acute exacerbations of asthma (34).

\section{Acknowledgments}

We thank Drs. Ian Morton and Judith Hall (King's College, London, UK) for their help in setting up the release technique, and the National Asthma Campaign, the British Lung Foundation, Fisons, and the Wellcome Trust for funding this work.

\section{References}

1. Barnes, P. J. 1986. Neural control of airways in health and disease. Am. Rev. Respir. Dis. 134:1289-1314.

2. Palmer, J. B. D., F. M. C. Cuss, and P. J. Barnes. 1986. VIP and PHM and their role in non-adrenergic inhibitory responses in isolated human airways. $J$. Appl. Physiol. 61:1322-1328.

3. Richardson, J. B. 1979. Nerve supply to the lung. Am. Rev. Respir. Dis. 119:785-802. 
4. Taylor, S. M., P. D. Paré, and R. R. Schellenburg. 1984. Cholinergic and non-adrenergic mechanisms in human and guinea pig airways. J. Appl. Physiol. 56:958-965.

5. Michoud, M.-C., R. Amyot, A. Jeanneret-Grosjean, and J. Couture. 1987. Reflex decrease of histamine-induced bronchoconstriction after laryngeal stimulation in humans. Am. Rev. Respir. Dis. 136:616-622.

6. Lammers, J.-W. J., P. Minette, M. McCusker, K. F. Chung, and P. J. Barnes. 1988. Non-adrenergic bronchodilator mechanisms in normal human subjects in vivo. J. Appl. Physiol. 64:1817-1822.

7. Ichinose, M., H. Inoue, M. Miura, and T. Takishima. 1988. Nonadrenergic bronchodilation in normal subjects. Am. Rev. Respir. Dis. 138:31-34.

8. Tucker, J. F., S. R. Brave, L. Charalambous, A. J. Hobbs, and A. Gibson 1990. $\mathrm{L}-\mathrm{N}^{\mathrm{G}}$-nitroarginine inhibits non-adrenergic, non-cholinergic relaxations of guinea-pig isolated tracheal smooth muscle. Br. J. Pharmacol. 102:663-664.

9. Li, C. G., and M. J. Rand. 1991. Evidence that part of NANC relaxan response of guinea-pig trachea to electrical field stimulation is mediated by nitric oxide. Br. J. Pharmacol. 102:91-94.

10. Ellis, J. L., and S. G. Farmer. 1989. Effects of peptidases on non-adrenergic, non-cholinergic inhibitory responses of tracheal smooth muscle: a comparison with effects on VIP- and PHI-induced relaxation. Br. J. Pharmacol. 96:521526.

1. Rees, D. D., R. M. J. Palmer, R. Schulz, H. F. Hodson, and S. Moncada 1990. Characterization of three inhibitors of endothelial nitric oxide synthase in vitro and in vivo. Br. J. Pharmacol. 101:746-752.

12. Belvisi, M. G., C. D. Stretton, M. Yacoub, and P. J. Barnes. 1992. Nitric oxide is the endogenous neurotransmitter of bronchodilator nerves in humans. Eur. J. Pharmacol. 210:221-222.

13. Belvisi, M. G., C. D. Stretton, M. Miura, G. M. Verleden, S. Tadjkarimi, M. H. Yacoub, and P. J. Barnes. 1992. Inhibitory NANC nerves in human tracheal smooth muscle: a quest for the transmitter. J. Appl. Physiol. 73:2505-2510.

14. Belvisi, M. G., C. D. Stretton, and P. J. Barnes. 1991. Nitric oxide modulates cholinergic neurotransmission in guinea-pig tracheal smooth muscle. Eur. $J$. Pharmacol. 198:219-222.

15. Belvisi, M. G., M. Miura, C. D. Stretton, and P. J. Barnes. 1993. Endogenous vasoactive intestinal peptide and nitric oxide modulate cholinergic neurotransmission in guinea pig trachea. Eur. J. Pharmacol. 231:97-102.

16. Brave, S. R., A. J. Hobbs, A. Gibson, and J. F. Tucker. 1991. The influence of $\mathrm{L}-\mathrm{N}^{\mathrm{G}}$-nitroarginine on field stimulation induced contractions and acetylcholine release in guinea pig isolated tracheal smooth muscle. Biochem. Biophys. Res. Commun. 179:1017-1022.

17. Fox, A. J., and I. K. M. Morton. 1990. An examination of the 5-HT receptor mediating contraction and evoked $\left[{ }^{3} \mathrm{H}\right]$-acetylcholine release in the guinea-pig ileum. Br. J. Pharmacol. 101:553-558.

18. Stretton, C. D., J. C. W. Mak, M. G. Belvisi, M. H. Yacoub, and P. J. Barnes. 1990. Cholinergic control of human airways in vitro following extrinsic denervation of the human respiratory tract by heart-lung transplantation. $\mathrm{Am}$. Rev. Respir. Dis. 142:1030-1033.
19. Rees, D. D., R. M. J. Palmer, H. F. Hodson, and S. Moncada. 1989. A specific inhibitor of nitric oxide formation from L-arginine attenuates endothelium-dependent relaxation. Br. J. Pharmacol. 96:418-424.

20. Bult, H., G. E. Boeck xstaens, P. A. Pelckkmans, F. H. Jordeans, Y. M Van Maercke, and A. G. Herman. 1990. Nitric oxide as an inhibitory non-adrenergic non-cholinergic neurotransmitter. Nature (Lond.). 345:346-347.

21. Rand, M. J. 1992. Nitrergic transmission: nitric oxide as a mediator of non-adrenergic, non-cholinergic neuro-effector transmission. Clin. Exp. Pharmacol. Physiol. 19:147-169.

22. Gillespie, J. S., X. Lui, and W. Martin. 1989. The effects of L-arginine and $\mathrm{N}^{\mathrm{G}}$-monomethyl $\mathrm{L}$-arginine on the response of the rat anococcygeus muscle to NANC nerve stimulation. Br. J. Pharmacol. 98:1080-1082.

23. Gibson, A., S. Mirzazadeh, A. J. Hobbs, and P. K. Moore. 1990. L-NG. monomethylarginine and $\mathrm{L}-\mathrm{N}^{\mathrm{G}}$-nitro arginine inhibit non-adrenergic non-cholinergic relaxation of the mouse anococcygeus muscle. Br. J. Pharmacol. 99:602606.

24. Li, C. G., and M. J. Rand. 1990. Evidence suggesting that nitric oxide (NO) mediates NANC neurotransmission in rat gastric fundus and anococcygeus muscle. Clin. Exp. Physiol. Pharmacol. Suppl. 16:184. (Abstr.)

25. Hecker, M., J. A. Mitchell, H. J. Harris, M. Katsura, C. Thiemermann, and J. R. Vane. 1990. Endothelial cells metabolize $\mathbf{N}^{\mathbf{G}}$-monomethyl-L-arginine to L-citrulline and subsequently to L-arginine. Biochem. Biophys. Res. Commun. 167:1037-1043

26. Bogle, R. G., S. Moncada, J. D. Pearson, and G. E. Mann. 1992. Identification of inhibitors of nitric oxide synthase that do not interact with the endothelial cell L-arginine transporter. Br. J. Pharmacol. 105:768-770.

27. Laitinen, A., M. Partanen, A. Hervonen, M. Petojuikko, and L. A. Laitinen. 1985. VIP-like immunoreactive nerves in human respiratory tract. Light and electron microscopic study. Histochemistry. 82:313-319.

28. Greenberg, B., K. Rhoden, and P. J. Barnes. 1987. Relaxant effects of vasoactive intestinal peptide and peptide histidine isoleucine in human and bovine pulmonary arteries. Blood Vessels. 24:45-50.

29. Altiere, R. J., J. L. Szarek, and L. Diamond. 1984. Neural control of relaxation in cat airways smooth muscle. J. Appl. Physiol. 57:1536-1544.

30. Palmer, J. B., A. P. Sampson, and P. J. Barnes. 1985. Cholinergic and non-adrenergic inhibitory responses in bovine airways: distribution and functional association. Am. Rev. Respir. Dis. 131:A283. (Abstr.)

31. Barnes, P. J. 1992. Modulation of neurotransmission in airways. Physiol. Rev. 72:699-729.

32. Wessler, I., D. Hellwig, and K. Racké. 1990. Epithelium-derived inhibition of $\left[{ }^{3} \mathrm{H}\right]$ acetylcholine release from the isolated guinea-pig trachea. NaunynSchmiedebergs Arch. Pharmakol. 342:387-393.

33. Rubanyi, G. M., and P. M. Vanhoutte. 1986. Oxygen derived free radicals, endothelium and responsiveness of vascular smooth muscle. Am. J. Physiol. 250:H815-H821.

34. Ward, M. J., J. T. Macfarlane, and D. Davies. 1985. A place for ipatropium bromide in the treatment of severe acute asthma. Br. J. Dis. Chest. 79:374378. 